\author{
Антонюк П.о. \\ кандидат економічних наук, науковий співробітник \\ відділ ринкових механізмів і структур \\ Інститут проблем ринку та економіко-екологічних \\ досліджень НАН України \\ Французький бульвар, 29, м. Одеса, Україна, 65044 \\ E-mail:paul_antonyuk@ukr.net \\ ORCID ID: 0000-0002-8100-2563 \\ Ступницька Т.М. \\ кандидат економічних наук, доцент \\ кафедра обліку та аудиту \\ E-mail: t.stupnitska@gmail.com \\ ORCID ID: 0000-0002-2517-2795
}

\author{
Антонюк О.П. \\ кандидат економічних наук, доцент \\ кафедра обліку та аудиту \\ E-mail: olegantoni@ukr.net \\ ORCID ID: 0000-0002-9182-4982
}

\section{Головаченко Л.М.}

асистент

кафредра обліку та аудиту

Одеська національна академія харчових технологій

вул. Канатна, 112, м. Одеса, Україна, 65039

E-mail: ludaoia2012@gmail.com

ORCID ID: 0000-0002-0059-019X

\title{
СТАН ТА РЕЗУЛЬТАТИ ТОРГІВЛІ АГРОПРОДОВОЛЬЧИМИ ТОВАРАМИ МІЖ УКРАЇНОЮ I ЄВРОПЕЙСЬКИМ СОЮЗОМ
}

В статті розглянуто сучасній стан торгівлі агропродовольчими товарами України та ЄС. Встановлено, що в останні роки країни ЄС стають одними із важливих імпортерів продукції сільського господарства та харчової промисловості, що пов'язується з дією зони вільної торгівлі. В товарній структурі експорту переважає сільськогосподарська продукція, проте її частка скорочується. Натомість зростає частка продукції харчової промисловості. Виконано порівняльний аналіз обсягів експорту та імпорту по товарах чотирьох розділів продукції відповідно до УКТЗЕД. Встановлено, що по товарах першого і четвертого розділів імпорт значно перевищує експорт. Натомість по товарах другого та третього розділів експорт перевищує імпорт формуючи значне додатне сальдо. В цілому результатом торгівлі агропродовольчими товарами з країнами $€ C$ є стійке позитивне сальдо, яке за період 2013-2017 рp. зросло в 2,6 рази.

Досліджено основні причини фрормування від'ємного сальдо по певним товарним групам. В статті підкреслюється, що основним шляхом отримання додатнього сальдо є зростання експорту, а не тільки зменшення імпорту. У висновках представлено рекомендації стосовно перспектив зростання виробництва та продажу агропродовольчої продукції на ринках ЄС.

Ключові слова: агропродовольча продукція, товарна структура, експорт, імпорт, сальдо, органічна продукція.

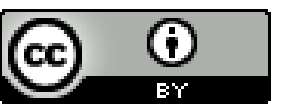

This work is licensed under a Creative Commons Attribution 4.0 International License http://creativecommons.org/licenses/by/4.0/
Постановка проблеми та їі зв'язок з важливими науковими та практичними завданнями. Важливим завданням зовнішньої торгівлі України $\epsilon$ досягнення бездефіцитності в торгівлі товарами. Особливе значення це питання має в торгівлі 3 нашим головним партнером - Свропейським Союзом, де формується переважна частина від'ємного сальдо держави. Завдяки дії Угоди зони вільної торгівлі Україна значно нарощує експорт в країні ЄС агропродовольчої продукції, однієї з небагатьох видів товарів 3 додатнім сальдо. Агропродовольча продукція займає значне місце в експорті нашої держави до Європейського Союзу й частка її постійно зростає, як і збільшується позитивний результат. Тому для України, постає питання опрацювання заходів щодо підвищення ефективності експортного потенціалу агропродоволь- чого сектору, його адаптації до нових відносин з європейськими країнами.

Аналіз останніх публікацій по проблемі. Досягнення стабільних результатів в зовнішній торгівлі агропродовольчими товарами потребує постійного аналізу як експортних операцій так і оцінки можливостей розширення присутності вітчизняних товарів на зовнішніх ринках. Дослідженням економічної інтеграції країни в світовий та європейський ринки агропродовольчої продукції займалися такі вченіекономісти, як: Б.В. Духницький, М.I. Пугачов, О.А. Мельник [3]. Кашуба Ю.П [4], Кириленко І.Г. [5], Пугачева К.М., Шеремет О.О. [6], Ю.О. Лупенко [7]. Разом із тим з огляду на підписання Угоди про асоціацію між Україною та СС необхідні додаткові дослідження зовнішньоторговельного балансу України на 
основі раціонального використання експортного агропродовольчого потенціалу.

Формування цілей дослідження. Метою даного дослідження є оцінка в рамках товарної структури обсягу, динаміки та результативності зовнішньої торгівлі агропродовольчими товарами і обгрунтування можливостей їх покращення.

Виклад основних результатів та їх обгрунтування. За останні п'ять років на фоні загального скорочення експорту з 62,3 млрд. дол. в 2013 р. до 43,3 млрд. дол. в 2017 р. в географічній структурі експорту товарів з України відбулися істотні зміни. Частка країн СНД скоротилась 334,8 \% до $16 \%$, а країн ЄС зросла з 26,6 \% до 40,5 \% і країни європейського співтовариства стають головним торговим партнером України. [1]

Значну частину в експорті товарів складає агропродовольча продукція. Це один 3 небагатьох видів товарів, експорт яких зріс за період 2013-2017 pp. 316930 млн. дол. до 17758 млн. дол., а їх частка в загальному експорті товарів, відповідно, 3 27,2 \% до 41,0 \%. Агропродовольча продукція 32014 р. стає головним експортним товаром України, що не кращим чином характеризує стан економіки та процеси, що в ній відбуваються. Так, в СС - лідеру по експорту продовольства доля сільськогосподарської сировини та сільгосппродукції в загальному обсязі європейського експорту складає сім процентів. Цей сегмент займає четверте місце по вартості експортних товарів після машин і обладнання, хімічної продукції та ліків [8].

Проте нарощування продовольчого експорту позитивно впливає на стан торгового балансу країни так як експорт агропродовольчої продукції забезпечує позитивне сальдо в зовнішній торгівлі цією продукцією, що постійно зростає: 38891 млн. дол. в 2013 р. до 13457 млн. дол. в 2017 p.

Важливе місце в торгівлі агропродовольчими товарами займають країни ЄС. Як відомо, 31 вересня 2017 р. набула повної міжнародно-правової чинності Угода про асоціацію між Україною і Європейським Союзом, включаючи створення поглибленої та всеосяжної зони вільної торгівлі, що почала діяти ще 31 січня 2016 p.

В останні два роки - 2016-2017 рр. істотно зріс експорт до країн ЄС як в цілому товарів, так і агропродовольчої продукції (табл. 1).

Експорт товарів з України до країн СС *

\begin{tabular}{|c|c|c|c|c|c|c|}
\hline \multirow{2}{*}{ Показники } & \multirow{2}{*}{2013 p. } & \multirow{2}{*}{$2015 \mathrm{p}$} & \multirow{2}{*}{2016 p. } & \multirow{2}{*}{2017 p. } & \multicolumn{2}{|c|}{2017 р. в \% до } \\
\hline & & & & & $2013 \mathrm{p}$. & $2015 \mathrm{p}$. \\
\hline 1. Експорт, всього, міл. дол. & 62302 & 38127 & 36362 & 43267 & 69,4 & 113,5 \\
\hline в т.ч. до країн $Є С$ & 16575 & 13020 & 13496 & 17539 & 105,8 & 134,7 \\
\hline частка країн $Є С$ в загальному експорті товарів, \% & 26,6 & 34,1 & 37,1 & 40,5 & $\mathrm{x}$ & $\mathrm{x}$ \\
\hline 2. Експорт агропродовольчої продукції, всього, & 16930 & 14563 & 15284 & 17758 & 104,9 & 121,9 \\
\hline $\begin{array}{l}\text { міл. дол. } \\
\text { в т.ч. до країн } € \mathrm{C}\end{array}$ & 4485 & 4081 & 4122 & 5617 & 125,2 & 137,6 \\
\hline $\begin{array}{l}\text { частка країн } Є С \text { в загальному експорті агропро- } \\
\text { довольчих товарів, \% }\end{array}$ & 26,5 & 28,0 & 27,0 & 31,6 & $\mathrm{x}$ & $\mathrm{x}$ \\
\hline
\end{tabular}

* розраховано авторами за даними Державної служби статистики України [2]

Як свідчать дані табл. 1 експорт до країн $Є С$ у 2017 р. перевищив рівень 2013 р. як по експорту всіх товарів, так і агропродовольчої продукції. Особливо високі темпи росту мали місце по групі агропродовольчих товарів, в результаті чого частка цієї продукції в загальному експорті товарів до країн СС зросла з $26,5 \%$ в 2013 р. до $31,6 \%$ в 2017 р.

Суттєве зростання експорту до країн Свро- пейського Союзу пояснюється однією причиною - це початок роботи зони вільної торгівлі Україна - ЄС, що відкрила європейський ринок для української продукції. Поряд 3 позитивною динамікою експорту важливою характеристикою зовнішньої торгівлі виступає товарна структура і які види продукції по глибині переробки і технологічності забезпечують це зростання (табл. 2).

Таблиця 2

Обсяг та товарна структура експорту агропродовольчої продукції з України в країни СС *

\begin{tabular}{|c|c|c|c|c|c|c|c|}
\hline \multirow{2}{*}{$\begin{array}{l}\text { Розділи продукції } \\
\text { відповідно до УКТЗЕД }\end{array}$} & \multicolumn{2}{|c|}{$2013 p}$. & \multicolumn{2}{|c|}{2016 p. } & \multicolumn{2}{|c|}{2017 p. } & \multirow{2}{*}{$\begin{array}{c}\text { Відхилення } 2017 \\
\text { р. від } 2013 \text { р. } \\
\text { млн. дол. }\end{array}$} \\
\hline & мЛн. дол. & $\%$ & млн. дол. & $\%$ & млн. дол. & $\%$ & \\
\hline $\begin{array}{l}\text { I. Живі тварини і продукти } \\
\text { тваринного походження }\end{array}$ & 55 & 1,2 & 175 & 4,3 & 283 & 5,0 & 228 \\
\hline $\begin{array}{l}\text { II. Продукти рослинного } \\
\text { походження }\end{array}$ & 3147 & 70,2 & 2042 & 49,5 & 2993 & 53,3 & -154 \\
\hline $\begin{array}{l}\text { III. Жири та олії тваринного } \\
\text { та рослинного походження }\end{array}$ & 501 & 11,2 & 1204 & 29,2 & 1476 & 26,3 & 975 \\
\hline IV. Готові харчові продукти & 782 & 17,4 & 701 & 17,0 & 865 & 15,4 & 83 \\
\hline Всього & 4485 & 100,0 & 4122 & 100,0 & 5617 & 100,0 & 1132 \\
\hline
\end{tabular}

*розраховано авторами за даними Державної служби статистики України [2] 
Основою агропродовольчого експорту як до країн ЄС так і по експорту в цілому залишається сільськогосподарська продукція. Але іiі частка за період 2013-2017 рр. скоротилась 3 71,4 \% до 58,3 \%. Натомість продукція харчової промисловості зросла з 28,6 $\%$ до 41,7 \% за рахунок жирів та олій рослинного походження. Якщо враховувати, що Україна експортує головнім чином нерафіновану олію стає зрозумілим, що експорт агропродовольчої продукції з України до ЄC базується на сировині та напівфабрикатах і приріст експорту відбувається саме за рахунок цих товарів. Подальше нарощування експорту до країн $\mathrm{CC}$ неможливе без розвитку високотехнологічних виробництв, про що свідчить досвід передових країн. Так у Франції, де агропродовольчий експорт значно переважає рівень України (61,2 Md € в 2017 р.) продукція харчової промисловості займає 77,3 \%, а сільського господарства 22,7 \% [11].

Ситуація з експортом до країн ЄС ускладнюється надзвичайною обмеженістю номенклатури товарів. Основою експорту агропродовольчих товарів відповідно до чотирьох розділів продукції УКТЗЕД є м'ясо та субпродукти свійської птиці, мед натуральний, пшениця, кукурудза, соєві боби, ріпак, олія соняшникова, макуха соняшникова. Серед численних найменувань товарних позицій експорту за чотиризначними кодами з групи 01-24 УКТЗЕД на ці вісім товарних позицій в 2013 р. і 2017 р. прийшлося, відповідно 84,9 \% і 83,0 \%валютної виручки з країн СС.
Це свідчить про низький ступень товарної диверсифікації експортних потоків агропромислової продукції до країн $С С$, що особливо примітно у порівняні з країнами СНД - в 2013 р. і 2017 р. аналогічний показник склав, відповідно 16,4 \% та 18,4\%.

Низький ступінь товарної диверсифікації експортних потоків до країн СС свідчить про високий рівень ї концентрації, що породжує значну залежність від кон'юнктури світових товарних ринків і насамперед від коливання цін. Період 2013-2017 рр. для наших експортерів характеризувався несприятливою кон'юнктурою і систематичним, з року в рік, зниженням експортних цін по основним видам продукції: м'ясо та субпродукти свійської птиці (\%) 10,3; мед 16,4 ; пшениця - 40,3; кукурудза - 33,9; соя - 24,9; ріпак - 18,9; олія соняшникова - 30,8. Про значні зменшення експортної виручки свідчать дані по експорту зерна кукурудзи. В 2013 р. до країн СС було продано 7135 тис. т. кукурудзі і експортна виручка склала 1654 млн. дол. В 2017 р. експорт кукурудзи зріс до 9238 тис. т., або на 129,5 \%, але експортна виручка скоротилась до 1416 млн. дол., або на 14,4 \%.

В географічній структурі експорту агропродовольчих товарів до країн СС виділяється група потужних імпортерів 3 обсягом закупівель більше 150 млн. дол. на рік, які власне і визначають обсяг і динаміку українського експорту. У табл. 3 наведено рейтинг найбільших імпортерів країн СС українських агропродовольчих товарів.

Таблиця 3

Найбільші імпортери країн СС агропродовольчих товарів з України *

\begin{tabular}{|c|c|c|c|c|c|c|c|c|}
\hline \multirow{2}{*}{$\begin{array}{l}\text { № } \\
\Pi / \Pi\end{array}$} & \multicolumn{2}{|c|}{2013 p. } & \multirow{2}{*}{$\begin{array}{l}\text { № } \\
\Pi / \Pi\end{array}$} & \multicolumn{2}{|c|}{2015 p. } & \multirow{2}{*}{$\begin{array}{l}\text { № } \\
\text { П/П }\end{array}$} & \multicolumn{2}{|c|}{2017 p. } \\
\hline & Країна & \% у експорті & & Країна & \% у експорті & & Країна & \% у експорті \\
\hline 1 & Іспанія & 16,9 & 1 & Іспанія & 20,9 & 1 & Нідерланди & 22,7 \\
\hline 2 & Нідерланди & 15,4 & 2 & Італія & 14,7 & 2 & Іспанія & 18,2 \\
\hline 3 & Італія & 13,3 & 3 & Нідерланди & 14,1 & 3 & Італія & 13,4 \\
\hline 4 & Польща & 11,8 & 4 & Польща & 10,4 & 4 & Польща & 9,2 \\
\hline 5 & Франція & 11,1 & 5 & Франція & 9,5 & 5 & Німеччина & 6,8 \\
\hline 6 & Бельгія & 5,2 & 6 & Португалія & 6,1 & 6 & Бельгія & 5,7 \\
\hline 7 & Португалія & 5,0 & 7 & Німеччина & 4,6 & 7 & Франція & 5,0 \\
\hline 8 & Німеччина & 5,0 & 8 & Бельгія & 4,3 & 8 & Португалія & 3,2 \\
\hline
\end{tabular}

Як свідчать дані на вісім найбільших імпортерів агропродовольчих товарів в 2013-2017 рр. приходиться близько 84 \% українського експорту. Географічна структура українського експорту свідчить, що в останні п'ять років напрями товарних потоків практично не змінилися. Враховуючи величезну ємність ринку $€ С$, в т.ч. і названих країн, динаміку експорту, українські експортери можуть розраховувати на подальше нарощування продаж значної частини продукції.

Суттєвим недоліком в торгівлі з країнами СС $\epsilon$ тенденція збільшення основними партнерами імпорту продукції рослинного походження, в основному пшениці, кукурудзи, соєвих бобів та ріпаку. Так, в 2017 р. частка продукції рослинного походження в агропродовольчому імпорті з України склала (\%): Німеччина - 71,4; Португалія - 86,0; Бельгія - 89,7. Імпортерами продукції з високою доданою вартістю серед найбільших партнерів залишаються Нідерланди, Польща, Франція, а також Балтійські країни.

Для України Європейський Союз це не тільки регіон, куди направляється значний обсяг нашого експорту. Не варто забувати, що європейські компанії більше зацікавлені не покупати українські товари, а продавати свої товари в Україні. Вже тривалий час імпорт товарів з СС перевищує їх експорт з України, обумовлюючи дефіцит в зовнішній торгівлі. Дещо інша ситуація спостерігається в торгівлі агропродовольчими товарами, про що розмова нижче.

Найменші за обсягом експортні поставки в 
країни СС агропродовольчої продукції $є$ по товарах першого розділу УКТЗЕД «Живі тварини, продукти тваринного походження». Причини цього чітко про- слідковуються порівнянням експорту та імпорту цих товарів у відношеннях України з країнами СС (табл. 4).

\section{Експорт та імпорт живих тварин і продукції тваринного походження *}

Таблиця 4

(млн. дол.)

\begin{tabular}{|l|c|c|c|c|c|c|}
\hline Код і назва товарів згідно з УКТЗЕД & 2013 р. & \multicolumn{3}{|c|}{2017 р. } \\
\cline { 2 - 6 } & Експорт & Імпорт & Сальдо & Експорт & Імпорт & Сальдо \\
\hline І. Живі тварини; продукти тваринного похо- & 55,2 & 668,6 & $-613,4$ & 282,6 & 328,7 & $-46,1$ \\
дження & & & & & \\
у тому числі: & & & & & \\
01. Живі тварини & 1,0 & 110,4 & $-109,4$ & 0,7 & 56,9 & $-56,2$ \\
02. М’ясо та їстивні субпродукти & 1,1 & 305,2 & 304,1 & 136,5 & 108,4 & 28,1 \\
03. Риба і ракоподібні & 7,2 & 111,3 & $-104,1$ & 20,2 & 78,3 & $-58,1$ \\
04. Молоко та молочні продукти; яйця птиці; & & & & & \\
натуральний мед & 41,1 & 133,5 & $-92,4$ & 120,8 & 80,2 & 40,6 \\
05. Інші продукти тваринного походження & 4,8 & 8,2 & $-3,4$ & 4,4 & 4,9 & $-0,5$ \\
\hline
\end{tabular}

* розраховано авторами за даними Державної служби статистики України [2]

Як видно з даних табл. 4 по живих тваринах і продукції тваринного походження до 2013 р. імпорт по усіх товарних групах 01-05 значно перевищує експорт формуючи значне від'ємне сальдо в сумі 613,4 млн. дол. Головною причиною цього $є$ недостатнє вітчизняне виробництво продукції тваринництва, відсутність ресурсів для експорту і необхідність насичення внутрішнього ринку в т.ч. і за рахунок імпорту. Дійсно, у порівнянні з 1990 р. виробництво продукції тваринництва 32017 р. склало (\%): м'ясо у забійній вазі - 53,2; молоко - 41,9; яйця птиці - 95,2. Проте після 2013 р. динаміка експорту та імпорту значно поліпшилась.

За період 2013-2017 рр. в рамках Угоди про асоціацію з СС вдалося значно наростити експорт цієї продукції - до 282,6 млн. дол., або в 5,1 р. і скоротити імпорт майже в два рази, а від'ємне сальдо довести до найнижчої за останні роки суми 46,1 млн. дол. Зростання експорту відбулося по продукції двох товарних груп 02 «М'ясо та їстивні субпродукти» і 04 «Молоко та молочні продукти; яйця птиці; натуральний мед».

Головним продуктом експорту продукції тваринного походження стає м'ясо та їстивні субпродукти свійської птиці, експорт якої виріс з 443 т в 2013 р. до 66750 т в 2017 р., а частка в товарах тваринного походження склала 47,3 \%. М'ясо птиці експортується в більшість країн $\mathrm{CC}$, але найбільшими партнерами 3 імпортом більше 4000 т є Нідерланди, Німеччина, Словаччина, Румунія. Серед країн Свропи нині Україна займає перше місце по експорту м'яса птиці в СС. Більш потужними експортерами м'яса в країни ЄС $€$ Таїланд і Бразилія. Основними факторами зростання українського експорту м'яса птиці є низька собівартість виробництва [12] та близькість європейського ринку. Зростає експорт натурального меду (це другий вид продукції по експортній виручці після м'яса свійської птиці). В 2017 р. в країни СС було експортовано меду на суму 98,7 млн. дол., або 34,9 \% всієї продукції тваринного походження. Країни ЄС основний ринок збуту меду з часткою 73,8 \% всього експорту. Зростає експорт молочної продукції, яєць та яєчної продукції i, особливо, масла вершкового по якому в 2017 р. Україна стала другою по обсягам поставок на ринок ЄС після Нової Зеландії. Всі види агропродовольчої продукції експортованої до країн ЕС відповідають самим високим вимогам стандартів співтовариства, що забезпечує постійно зростання обсягів експорту. В свою чергу наявність сертифікатів ЕС значно спрощує для українських експортерів дорогу до інших ринків. Так за 2013 - 2017pp. імпорт м'яса та субпродуктів свійської птиці з України зріс країнами Азії в 2,2 рази, а країнами Африки в 6,1 рази. В той же час залишаються товари, для яких встановлені СС квоти не були використані: м'ясо ВРХ, баранина, свинина, продукція з обробленого молока і ряд інших. Квоти на м'ясо взагалі не використовуються по причині недостатнього вітчизняного виробництва i відсутності необхідних ресурсів для експорту. Лише на поставках м'яса ВРX та свинини в межах квот, відповідно, 12000 т та 20000 т на рік експорт може зростати щорічно на суму близько 128,6 млн. дол.

Слід відзначити, що дійсно значне зростання експорту до СС виявилось недостатнім для компенсації скорочення експорту цієї групи товарів до країн СНД з 789 млн. дол. в 2013 р. до 254 млн. дол. в 2017 p. Переорієнтація таких значних товарних потоків 3 ринку СНД на інші ринки, в т.ч. і ринок $Є С$, потребує часу і значних коштів.

Продукти рослинного походження складають найбільшу частку в українському агропродовольчому експорті до країн СС, крім того по цих продуктах держава має стабільне та зростаюче позитивне сальдо. Основний обсяг як експорту так і імпорту приходиться на чотири товарні групи 07 «Овочі»; 08 «Їстивні плоди та горіхи»; 10 «Зернові культури»; 12 «Насіння та плоди олійних культур» (табл. 5). Найбільш проблемними з точки зору реалізації на ринках СС $\epsilon$ овочі і їстивні плоди та горіхи. До 2013 р. по цих товарних групах було значне від'ємне товарне сальдо. Ситуація стала змінюватись під впливом дії зони вільної торгівлі. 
Експорт та імпорт продуктів рослинного походження *

\begin{tabular}{|l|c|c|c|c|c|c|}
\hline \multicolumn{1}{|c|}{$\begin{array}{c}\text { Код і назва товарів згідно 3 } \\
\text { УКТЗЕД }\end{array}$} & \multicolumn{3}{|c|}{2013 р. } & \multicolumn{3}{c|}{ (млн. дол.) } \\
\cline { 2 - 7 } & експорт & імпорт & сальдо & експорт & імпорт & сальдо \\
\hline $\begin{array}{l}\text { II. Продукти рослинного похо- } \\
\text { дження }\end{array}$ & 3147,0 & 890,0 & 2257,0 & 2993,3 & 469,8 & 2523,5 \\
\hline $\begin{array}{l}\text { 06. Живі дерева та інші росли- } \\
\text { ни }\end{array}$ & 0,4 & 92,2 & $-91,8$ & 1,2 & 21,8 & $-20,6$ \\
\hline 07. Овочі & 22,7 & 62,1 & $-39,4$ & 35,7 & 24,0 & 11,7 \\
\hline 08.Їстивні плоди та горіхи & 82,5 & 258,6 & $-176,1$ & 139,2 & 95,9 & 43,3 \\
\hline 09. Кава, чай & 2,7 & 81,0 & $-78,3$ & 3,3 & 64,1 & $-60,8$ \\
\hline 10. Зернові культури & 1728,6 & 220,8 & 1507,8 & 1687,3 & 113,0 & 1574,3 \\
\hline $\begin{array}{l}\text { 11. Продукція борошномель- } \\
\text { ної промисловості }\end{array}$ & 8,3 & 7,8 & 0,5 & 18,3 & 8,5 & 9,8 \\
\hline $\begin{array}{l}\text { 12. Насіння і плоди олійних } \\
\text { культур }\end{array}$ & 1248,4 & 145,6 & 1102,8 & 1085,1 & 128,8 & 956,3 \\
\hline 13. Шелак природній & 0,1 & 21,9 & $-21,8$ & 0,1 & 13,7 & $-13,6$ \\
\hline $\begin{array}{l}\text { 14. Рослинні матеріали для } \\
\text { виготовлення }\end{array}$ & 53,3 & - & 53,3 & 23,1 & - & 23,1 \\
\hline
\end{tabular}

* розраховано авторами за даними Державної служби статистики України [2]

В останні роки в Україні поступово зростає виробництво овочів та фруктів. Нині Україна займає п’яте місце в Європі по рівню виробництва плодоовочевої та ягідної продукції і являється одинадцятою з 45 країн Свропи по органічному землеробству [10 ]. Погіршення торговельних відносин з Російською Федерацією явилось поштовхом до модернізації плодоовочевого сектору і переорієнтації на протязі останніх двох років, експорту більшості овочів і фруктів з РФ до Європейського Союзу та інших регіонів світу. Європейський ринок надзвичайно конкурентний і $\mathrm{CC}$ має ЗВТ з великою кількістю країн - експортерів плодоовочевої продукції - Єгипет, Туреччина, Ізраїль, Чілі, ПАР та інші. Експортована продукція має відповідати сучасним умовам якості надзвичайно вибагливого ринку СС. Проте за короткий період не вдалося створити відповідну інфраструктуру, опрацювати маркетинг, що значно ускладнює процес реалізації плодоовочевої продукції та ягід і зменшує експортні можливості.

В експорті до країн ЄС більшу частину складають сушені та морожені продукти (овочі, бобові, сушені, лущені, очищені; овочі морожені). Але поступово зростає експорт в країни $С С$ і свіжих овочей помідори, цибуля, огірки, спаржа, баклажани, селера, експортна виручка за які в 2017 р. склала 11,6 млн. дол. або 31,7 \% овочевого експорту. Найбільшим імпортером овочів з України з країн СС є Польща (помідори, цибуля, огірки, інші овочі) з часткою в 2017 p. 26,5 \% європейського імпорту. Зростає імпорт овочів до Нідерландів, Румунії, Італії, Німеччини.

Більш динамічно розвивається експорт до країн ЄС їстивних плодів та горіхів - з 89,5 млн. дол. в 2013 р. до 139,2 млн. дол. в 2017 р. Країни ЄС, споживають більше $70 \%$ українського експорту цієї продукції. Найбільший попит в ЄС традиційно мають волоські горіхи (очищені) та ягоди морожені, експорт яких в 2017 р. приніс, відповідно, 58,5 млн. дол. і 57,6 млн. дол. Постійно зростають поставки до ЄС свіжих ягід - малина, чорниця, лохина, ожина (підгрупа 0810) яблук та груш (0808), абрикоси, вишня, черешня, слива, терен (0809). Українські експортери їстивних плодів та горіхів мають можливості для подальшого нарощування експорту цієї продукції до країн $\mathrm{EC}$, так як відповідно до Угоди про асоціацію між Україною та СС, ставки увізних мит СС для більшості позицій груп 08 були знижені до 0 \% [9]. Найбільшими споживачами продукції українського садівництва в СС за даними 2017 р.(в \% до загального експорту групи 08) стали: Польща - 29,0; Франція - 10,7; Нідерланди - 8,4; Греція - 7,3; Італія - 6,3.

Найбільшу частку в експорті до країн СС продукції з високою доданою вартістю займають жири та олії тваринного та рослинного походження, головним чином, олія соняшникова. Поставки в СС цієї продукції відбувались в умовах постійного зниження експортних цін (дол./т); 2013 р. - 1080; 2014 р. - 843; 2015 р. - 778; 2016 р. - 769; 2017 р. - 747, що явилося хорошим стимулом для збільшення партнерами з СС закупівель олії з 386 тис. т. в 2013 р. до 1331 тис. т. Значно менше експортується соєвої та ріпакової олій, 3 огляду на те що соя та ріпак переважно йдуть на експорт по причині відсутності експортного мита. Проте країни ЕС є важливими імпортерами соєвої та ріпакової олій. Впродовж 2016 - 2017pр. на цей ринок прийшлось 85,2 \% українського експорту ріпакової олії і 43\% соєвої. Збільшення переробки на вітчизняних заводах сої та ріпаку реальний шлях для експорту готової продукції (олії, макухи), тобто продукції 3 високою доданою вартістю, в т.ч. і на ринки СС.

Лідерами по імпорту соняшникової олії, в основному нерафінованої, являються Іспанія, Італія, Нідерланди і Франція, компанії яких після доведення нерафінованого продукту до необхідних стандартів продають його під своїми торговими марками 3 немалою вигодою для себе. Для України нарощування 
експорту рослинних олії в країни СС дає можливість збільшувати додатне сальдо (млн. дол.): 2013 р. - 361; 2015 p. $-630 ; 2017$ p. -1422.

Україна має можливість збільшити експорт в країни ЕС за рахунок органічної продукції. В більшості країн Європи частка органічного землеробства охоплює 5 - 10\% сільськогосподарських угідь, в той час як в Україні 1,0\%, що означає хороші перспективи для росту. Попит на органічну продукцію зростає швидше ніж пропозиція, тому в Свропейському Союзі зацікавленні в нарощуванні такого виробництва в Україні, до чого відносяться зернові (головне кукурудза, пшениця), бобові, олійні, овочі, фрукти, ягоди, лікарські рослини та продукти переробки. В органічному експорті з України дуже незначна частка переробленої продукції - яблучний концентрат, борошно твердої пшениці, соняшникова олія та макуха, молочні продукти та інші. Переважають в органічному експорті, як і у звичайному експорті, різні види сировини. Головними країнами - імпортерами української органічної продукції є Нідерланди, Німеччина, Великобританія, а всього в 2017p. обсяг експорту оцінюється в сумі 99 млн. євро.

В значно менших обсягах в порівнянні з жирами та оліями тваринного та рослинного походження в країни СС експортується така продукція з високою добавленою вартістю, як «Готові харчові продукти» - IV розділ продукції відповідно до УКТЗЕД (табл. 6).

Як видно з даних табл. 6 по готових харчових продуктах Україна виступає переважно як імпортер. При цьому країни ЄС є основні поставщики готових харчових продуктів. 3 усіх імпортованих Україною в 2017 р. готових харчових продуктів на суму 1935 млн. дол. 1162 млн. дол., або 60,1% приходиться на країни $\mathrm{CC.}$

Таблиця 6

Експорт та імпорт готових харчових продуктів *

\begin{tabular}{|c|c|c|c|c|c|c|}
\hline \multirow{3}{*}{$\begin{array}{c}\text { Код і назва товарів згідно з } \\
\text { УКТЗЕД }\end{array}$} & \multicolumn{3}{|c|}{2013 p. } & \multicolumn{3}{|c|}{2017 p. } \\
\hline & \multicolumn{3}{|c|}{ млн. дол. } & \multicolumn{3}{|c|}{ млн. дол. } \\
\hline & Експорт & Імпорт & Сальдо & Експорт & Імпорт & Сальдо \\
\hline IV Готової харчові продукти & 781,8 & 1416,8 & $-635,0$ & 864,7 & 1161,9 & $-297,2$ \\
\hline 16. Продукти з м’яса, риби & 1,9 & 49,2 & $-47,3$ & 2,8 & 33,0 & $-30,2$ \\
\hline $\begin{array}{l}\text { 17. Цукор і кондитерські вироби } 3 \\
\text { цукру }\end{array}$ & 29,1 & 23,2 & 5,9 & 53,2 & 31,5 & 21,7 \\
\hline 18. Какао та продукти з нього & 19,4 & 150,7 & $-131,3$ & 38,2 & 130,3 & $-92,1$ \\
\hline 19. Готові продукти із зерна & 26,3 & 124,0 & $-97,7$ & 96,1 & 98,4 & $-2,3$ \\
\hline 20. Продукти переробки овочів & 161,0 & 125,5 & 35,5 & 109,1 & 87,2 & 21,9 \\
\hline 21. Різні харчові продукти & 21,1 & 380,2 & $-359,1$ & 36,1 & 254,2 & $-218,1$ \\
\hline $\begin{array}{l}\text { 22. Алкогольні і безалкогольні напої } \\
\text { та оцет }\end{array}$ & 25,4 & 285,2 & $-259,8$ & 26,6 & 245,2 & $-218,6$ \\
\hline $\begin{array}{l}\text { 23. Залишки і відходи харчової } \\
\text { промисловості }\end{array}$ & 497,6 & 198,7 & 298,9 & 497,5 & 140,5 & 357,0 \\
\hline $\begin{array}{l}\text { 24. Тютюн і промислові замінники } \\
\text { тютюну }\end{array}$ & - & 80,1 & $-80,1$ & 5,1 & 141,6 & $-136,5$ \\
\hline
\end{tabular}

* розраховано авторами за даними Державної служби статистики України [2]

Ринок готових харчових продуктів має свої особливості, а саме це власне продукти харчування (товарні групи 16-22 УКТЗЕД), а також 23 - «Залишки і відходи харчової промисловості» та 24 - «Тютюн і промислові замінники тютюну». В структурі експорту готових харчових продуктів з України в країни СС переважають не продукти харчування, а залишки і відходи харчової промисловості, з часткою 63,6 \% в 2013 p. i 57,5 \% в 2017 р., які забезпечують значне і стабільне позитивне сальдо. Основні торгові партнери України не дуже зацікавлені в імпорті продуктів харчування з України. Вони зосереджені на імпорті лише залишків і відходів харчової промисловості, які в 2017 р. склали в імпорті готових харчових продуктів (в \%): Іспанія - 91,5; Італія - 96,9; Нідерланди 83,3; Франція - 97,8. Враховуючи що європейський ринок вже перенасичений продуктами харчування нашим експортерам слід бути готовими до жорстокої конкуренції з боку європейських поставщиків. Масш- таби та динаміка нашого експорту свідчать про реальні можливості зростання продаж цукру і кондитерських виробів 3 цукру, готових продуктів із зерна, продуктів переробки овочів, різних харчових продуктів. Саме ці види продукції переважають в експорті до основних партнерів України по групі продуктів харчування.

Основними покупцями цукру і кондвиробів 3 цукру є Греція, Литва, Польща, Румунія, Угорщина; продуктів із зерна - країни Балтії, Німеччина, Румунія, Польща; продуктів переробки овочів - Австрія, Німеччина, Польща; різних харчових продуктів - Латвія, Литва, Польща, Румунія. В останні роки серед країн СС Польща являється найбільшим імпортером продуктів харчування з України.

За 2013-2017 pр. Україна поліпшила свої результати в торгівлі агропродовольчими товарами 3 країнами $С С$ - зростає експорт, скорочується імпорт, збільшується позитивне сальдо (табл. 7). 
Баланс зовнішньої торгівлі України та СС в торгівлі агропродовольчими товарами *

Таблиця 7

\begin{tabular}{|l|c|c|c|c|c|c|}
\hline \multicolumn{1}{|c|}{ Розділи продукції відповідно до } \\
\begin{tabular}{l} 
УКТЗЕД \\
\cline { 2 - 7 }
\end{tabular} & експорт & імпорт & сальдо & експорт & імпорт & сальдо \\
\hline $\begin{array}{l}\text { I. Живі тварини і продукти тварин- } \\
\text { ного походження }\end{array}$ & 55 & 668 & -613 & 283 & 329 & -46 \\
\hline $\begin{array}{l}\text { II. Продукти рослинного походжен- } \\
\text { ня }\end{array}$ & 3147 & 890 & 2257 & 2993 & 470 & 2523 \\
\hline $\begin{array}{l}\text { III. Жири та олії тваринного та рос- } \\
\text { линного походження }\end{array}$ & 501 & 140 & 361 & 1476 & 50 & 1426 \\
\hline IV. Готові харчові продукти & 782 & 1417 & -635 & 865 & 1162 & -297 \\
\hline Всього & 4485 & 3115 & 1370 & 5617 & 2011 & 3606 \\
\hline
\end{tabular}

* розраховано авторами за даними Державної служби статистики України [2]

Наведена в табл. 7 інформація свідчить про переважання в експорті продукції рослинного походження, де формується основа позитивного сальдо i високу питому вагу імпорту готової харчової продукції в загальному обсязі імпорту продукції сільського господарства та харчової промисловості, що приводить до значного від'ємного сальдо.

Продукти рослинного походження та олії рослинного походження, що мають конкурентні переваги на зовнішніх ринках забезпечують позитивне сальдо у зовнішній торгівлі. Продукти тваринного походження і продукти харчування, що не мають достатніх конкурентних переваг формують від’ємне сальдо. Проте зростання експорту і значне зменшення імпорту цих продуктів свідчить про певні позитивні зміни в останні два роки. Слід зауважити, що приріст позитивного сальдо відбувається в більшій мірі за рахунок зростання експорту, а не скорочення імпорту.

Висновки та перспективи подальших досліджень. В період 2013-2017 рр. країни Свросоюзу стають головним імпортером продукції з України i одним з основних імпортерів агропродовольчої продукції, що дає підстави говорити про певні економічні результати реалізації Угоди про асоціацію. В ході дослідження використовується головним чином товарна структура експорту та імпорту по чотирьох розділах продукції і товарним групам по кожному розділу. Саме такий порядок дослідження дає змогу оцінювати як стан взаємної торгівлі, так і ії результати .

Впродовж досліджуваного періоду зменшується в експорті частка сільськогосподарської продукції з 71,4 \% в 2013 р. до 58,3 \% в 2017 р., а частка продукції харчової промисловості зростає, відповідно, $з 28,6 \%$ до 41,7 \% за рахунок жирів та олій рослинного походження.

Головними товарами експорту продукції тваринного походження стають м'ясо та їстивні субпродукти свійської птиці, молочні продукти та натуральний мед, що дало можливість досягти вперше позитивного сальдо по товарних групах 02 і 04 і значно зменшити від'ємне сальдо по товарах першої групи.

По продукції рослинного походження спад експорту в цілому пояснюється зниженням цін на зерно і насіння олійних культур. Проте по двох товарних групах 07 і 08 експорт зростає по таких видах продукції, які раніше слабо були представлені на ри- нку СС: свіжі овочі, волоські горіхи, ягоди. Країни ЄC стають основним ринком для продукції товарної групи 08. Зростання експорту цих видів продукції при одночасному скороченні імпорту дало можливість ліквідувати від'ємне сальдо. Найбільшу частку в експорті продукції з високою доданою вартістю займає олія соняшникова, продаж якої зріс з 386 тис. т в 2013 р. до 1331 тис. т в 2017 р. забезпечивши при цьому значне додатне сальдо. Менш помітно подіяла зона вільної торгівлі на експорт готових харчових продуктів. Як і раніше головним товаром тут $є$ залишки i відходи харчової промисловості, головним чином макуха олійних культур. Певний прогрес в експорті був по цукру і кондитерським виробам з цукру, какао i продуктам з нього і готовим продуктам із зерна. Ринок ЄС насичений продукцією 3 жорстокою конкуренцією між виробниками. Виконана оцінка стану та результатів торгівлі України і ЕС дає підставу говорити про наявність резервів збільшення експорту агропродовольчої продукції.

По - перше, повне освоєння квот на безмитну поставку продукції тваринного походження в т.ч. яловичини, свинини, баранини, сухого молока.

По - друге, щоб успішно вийти на ринок ЕС 3 такою продукцією як овочі, фрукти i, особливо, ягоди необхідно створити весь комплекс доопрацювання продукції - сортування , упаковка, охолодження, заморозка зберігання.

По - третє, зростання переробки сої та ріпаку дозволить збільшити до країн ЕС експорт готової продукції - олії, макухи, які вже нині є одними з основних імпортерів цих видів продукції.

По - четверте, збільшити експорт можливо за рахунок розширення виробництва органічної продукції, попит на яку в країнах ЕС не покривається власними можливостями і країни співтовариства зацікавленні в нарощуванні такого виробництва в Україні.

Попри складні умови входження в ринок $\mathrm{CC}$ слід позитивно оцінити результати торгівлі, особливо в два останні роки 2016-2017 pр. Зростання експорту і зменшення імпорту дали можливість значно збільшити позитивне сальдо в торгівлі агропродовольчими товарами. В подальшому дослідження можуть бути направлені на визначення шляхів реалізації виявлених резервів збільшення експорту агропородовольчої продукції. 


\section{Література}

1. Антонюк О.П., Антонюк П.О., Лисюк В.М. Аналіз динаміки та структура експорту агропродовольчої продукції // Економіка харчової промисловості. 2017. Т.9, вип. 3. C. 8-15; DOI: 10.15673/fie.v9i3.619 20.12.2018)

2. Державна служба статистики України: веб-сайт. URL: http://www.ukrstat.gov.ua/ (дата звернення

3. Перспективи розвитку зовнішньоторговельних відносин України з Свропейським Союзом в аграрній сфері / Духницький Б.В. та ін.; за ред. М.І. Пугачова. К.: ННЦІПЕ, 2016. 40 с.

4. Кашуба Ю.П. Експортні можливості аграрних підприємств України на ринках ЄС // Економіка АПК. 2017. № 10. С. 70-73

5. Кириленко І.Г., Івченко В.С., Деменчук В.В. Основні тенденції розвитку світового продовольчого ринку та виробництва продовольства в Україні // Економіка АПК. 2018. № 9. С. 34-43

6. Пугачова К.М., Шеремет О.О. Зовнішньоторговельні відносини України з ЄС // Економіка АПК. 2018. № 2. С. $85-89$

7. Формування глобального і регіонального ринків сільськогосподарської сировини та продовольства: монографія / Ю.О. Лупенко, та ін.; за ред. Ю.О. Лупенка, М.І. Пугачова. К.: ННЦІАЕ, 2015. 320 с.

8. ЕС стал мировым лидером по экспорту продовольствия: веб-сайт. URL: http://www.dw.com/ru/ecстал-мировым-лидером-по-экспорту-продовольствия/а-17731268 (дата звернення 18.12.2018)

9. Експорт плодів та горіхів до $\mathrm{CC}$ : перші кроки: веб-сайт. URL: http://agrobusiness.com.ua/agrobusiness/item/10213-eksport-plodiv-ta-horikhiv-do-yes-pershi-kroky.html (дата звернення 18.12.2018)

10. США: Україна має можливості стати світовим лідером з експорту овочів та фруктів: веб-сайт. URL: https://mind.ua/news/20175683-ssha-ukrayina-mae-mozhlivosti-stati-svitovim-liderom-z-eksportu-ovochiv-tafruktiv (дата звернення 20.12.2018)
11. Commerce
exterieur
Resultats
2017:
веб-сайт.
URL: https://www.tresor.economie.gouv.fr/Articles/2018/02/08/commerce-exterieur-de-la-france-resultats-2017 (дата звернення 21.12.2018)

12. Украина - крупнейший экспортер курятины в EC: веб-сайт. URL: https:/delo.ua/business/ukrainaokazalas-liderom-po-eksportu-mjasa-pticy-v-es-340095/ (дата звернення 20.12.2018)

Стаття надійшла 28.12.2018 Стаття прийнята до друку 12.01.2019 Доступно в мережі Internet 19.03.2019

\author{
Антонюк П.О. \\ кандидат економических наук, научный сотрудник \\ отдел рыночных механизмов и структур \\ Институт проблем рынка и экономико-экологических \\ исследований НАН Украины \\ Французский бульвар, 29, г.Одесса, Украина, 65044 \\ E-mail:paul_antonyuk@ukr.net \\ ORCID ID: 00000-0002-8100-2563 \\ Ступницкая Т.M. \\ кандидат экономических наук, доцент \\ кафедра учета и аудита \\ E-mail: t.stupnitska@gmail.com \\ ORCID ID: 0000-0002-2517-2795
}

\author{
Антонюк О.П. \\ кандидат экономических наук, доцент \\ кафедра учета и аудита \\ E-mail: olegantoni@ukr.net \\ ORCID ID: 0000-0002-9182-4982
}

\section{Головаченко Л.М.}

ассистент

кафедра учета и аудита

Одесская национальная академия пищевых технологий

ул. Канатная, 112, г. Одеса, Украина, 65039

E-mail: ludaoia2012@gmail.com

ORCID ID: 0000-0002-0059-019X

\section{СОСТОЯНИЕ И РЕЗУЛЬТАТЫ ТОРГОВЛИ АГРОПРОДОВОЛЬСТВЕННЫМИ ТОВАРАМИ МЕЖДУ УКРАИНОЙ И ЕВРОПЕЙСКИМ СОЮЗОМ}

В статье исследуются вопросы современного состояния торговли агропродовольственными товарами Украины и ЕС. Установлено, что в последние годы страны ЕС становятся одними из важнейших импортеров продукции сельского хозяйства и пищевой промышленности, что связывается с действием зоны свободной торговли. 
Установлено, что экспорт в страны ЕС усложняется чрезвычайно ограниченной номенклатурой товаров. Основой экспорта есть лишь восемь товарных позиций: мясо птицы, мёд натуральный, пшеница, кукуруза, соевые бобы, рапс, масло подсолнечное нерафинированное и шрот масличных культур, на которые приходится 83.0 - 84,9\% всей суммы экспорта. Имеет место тенденция увеличения основными партнерами ЕС импорта только продукции растительного происхождения.

В анализе товарной структуры экспорта установлено преобладание сельскохозяйственной продукции, однако ее удельный вес постепенно сокращается при возрастании продукции пищевой промышленности. Выполнен сравнительный анализ объемов экспорта и импорта по товарам четырех разделов продукции соответственно с УКТВЭД. Исследование показывает, что по товарам животного происхождения и готовым пищевым продуктам импорт значительно превышает экспорт, несмотря на то, что в последние годы по этим продуктам украинский экспорт динамично развивается. В тоже время по продуктам растительного происхождения и жирам и маслам животного и растительного происхождения формируется постоянно возрастающее положительное сальдо, которое и определяет результаты в целом. Положительное сальдо за период 2013-2017 гг. возросло в 2,6 раза.

Исследованы основные причины формирования отрицательного сальдо по определенным товарным группам. В работе подчеркивается, что основным путем достижения положительного сальдо должно стать всемерное увеличение экспорта, а не только сокращение импорта.

На основе проведенного анализа представлены рекомендации по увеличению производства и продаж продукции некоторых товарных групп на рынках ЕC.

Ключевые слова: агропродовольственная продукция, товарная структура, экспорт, импорт, сальдо, органическая продукция.

Antonyuk P.

Ph.D., Researcher

Department of Market Mechanisms and Structures Institute of Market Problems and Economic \& Ecological Research of National Academy of Sciences of Ukraine

Frantsuzskiy boulevard, 29, Odesa, Ukraine, 65044

E-mail: paul_antonyuk@ukr.net

ORCID ID: 0000-0002-8100-2563

Stupnytska T.

Ph.D., Associate Professor

Department of Accounting and Auditing

E-mail: t.stupnitska@gmail.com

ORCID ID: 0000-0002-2517-2795
Antonyuk 0.

Ph.D., Associate Professor

Department of Accounting and Auditing

E-mail: olegantoni@ukr.net

ORCID ID: 0000-0002-9182-4982

Holovachenko L.

Assistant

Department of Accounting and Auditing

Odesa National Academy of Food Technologies

Kanatna str., 112, Odesa, Ukraine, 65039

E-mail: ludaoia2012@gmail.com

ORCID ID: 0000-0002-0059-019X

\section{CONDITION AND RESULTS OF TRADING OF THE AGRI-FOOD PRODUCTS BETWEEN UKRAINE AND THE EUROPEAN UNION}

The article examines the current state of trade of agri-food products of Ukraine and the EU. It has been established that in recent years, the EU countries have become one of the most important importers of agricultural and food products, which is associated with the operation of the free trade zone.

It has been established that export to EU countries is complicated by an extremely limited range of goods. The basis of export is only eight commodity items: poultry meat, natural honey, wheat, corn, soybeans, rapeseed, unrefined sunflower oil and oilseed meal, which account for $83.0-84.9 \%$ of the total exports. There is a tendency for the main EU partners to increase imports of plant products only.

In the analysis of the export commodity structure, the prevalence of agricultural products was established, but its share is gradually reduced with an increase in food production. A comparative analysis of the volume of exports and imports was carried out for the goods of the four product sections, respectively, with UKTVED. The study shows that imports of animal products and prepared food products significantly exceed exports, despite the fact that in recent years, Ukrainian exports have been dynamically developing for these products. At the same time, products of plant origin and fats and oils of animal and vegetable origin form a constantly growing positive balance, which determines the results as a whole. The surplus for the period 2013-2017. increased by 2.6 times.

The main causes of the formation of a negative balance for certain product groups have been investigated. The paper emphasizes that the main way to achieve a positive balance should be a substantial 
increase in exports, and not just a reduction in imports. Based on the analysis, recommendations are presented for increasing the production and sales of products of certain product groups in the EU markets.

Key words: agri-food products, commodity structure, export, import, balance, organic products.

\section{References}

1. Antoniuk, O. P., Antoniuk, P. O., \& Lysiuk, V. M. (2017). Analiz dynamiky ta struktura eksportu ahroprodovolchoi produktsii. Ekonomika Kharchovoi Promyslovosti, 9(3), 8-15. doi:10.15673/fie.v9i3.619

2. Derzhavna sluzhba statystyky Ukrainy. Retrieved December 20, 2018, from http://www.ukrstat.gov.ua/

3. Dukhnytskyi, B. V. (2016). Perspektyvy rozvytku zovnishnotorhovelnykh vidnosyn Ukrainy z Yevropeiskym Soiuzom v ahrarnii sferi (M. I. Puhachov, Ed.). Kiev: NNTsIPE.

4. Kashuba, Yu. P. (2017). Eksportni mozhlyvosti ahrarnykh pidpryiemstv Ukrainy na rynkakh YeS. Ekonomika APK, (10), 70-73.

5. Kyrylenko, I. H., Ivchenko, V. Ye., \& Demenchuk, V. V. (2018). Osnovni tendentsii rozvytku svitovoho prodovolchoho rynku ta vyrobnytstva prodovolstva v Ukraini. Ekonomika APK, (9), 34-43.

6. Puhachova, K. M., \& Sheremet, O. O. (2018). Zovnishnotorhovelni vidnosyny Ukrainy z YeS. Ekonomika $A P K,(2), 85-89$.

7. Lupenko, Yu. O. (2015). Formuvannia hlobalnoho i rehionalnoho rynkiv silskohospodarskoi syrovyny ta prodovolstva (Yu. O. Lupenko \& M. I. Puhachov, Eds.). Kiev: NNTsIAE.

8. ES stal mirovym liderom po eksportu prodovolstviia. (2014). Retrieved December 18, 2018, from https://www.dw.com/ru/ec-стал-мировым-лидером-по-экспорту-продовольствия/а-17731268

9. Eksport plodiv ta horikhiv do YeS: Pershi kroky. (2018). Retrieved December 18, 2018, from http://agrobusiness.com.ua/agrobusiness/item/10213-eksport-plodiv-ta-horikhiv-do-yes-pershi-kroky.html

10. SShA: Ukraina maie mozhlyvosti staty svitovym liderom $z$ eksportu ovochiv ta fruktiv. (2017). Retrieved December 20, 2018, from https://mind.ua/news/20175683-ssha-ukrayina-mae-mozhlivosti-stati-svitovim-liderom-zeksportu-ovochiv-ta-fruktiv

11. Commerce exterieur Resultats 2017. (2018). Retrieved December 21, 2018, from https://www.tresor.economie.gouv.fr/Articles/2018/02/08/commerce-exterieur-de-la-france-resultats-2017

12. Ukraina krupneishii eksporter kuriatiny v ES. (2018). Retrieved December 20, 2018, from https://delo.ua/business/ukraina-okazalas-liderom-po-eksportu-mjasa-pticy-v-es-340095/

Received 28 December 2018

Approved 12 January 2019

Available in Internet 19.03.2019

Цитування згідно ДСТУ 8302:2015

Антонюк П.О., Антонюк О.П., Ступницька Т.М., Головаченко Л.М. Стан та результати торгівлі агропродовольчими товарами між Україною і Європейським союзом // Економіка харчової промисловості. 2019. Т.11, вип. 1. С. 27-36;

doi: 10.15673/fie.v11i1.1292

Cite as APA style citation

Antonyuk P., Antonyuk O., Stupnytska T., \& Holovachenko L. (2019). Condition and results of trading of the agri-food products between Ukraine and the European union. Food Industry Economics, 11(1), 27-36; doi: 10.15673/fie.v11i1.1292 